\title{
Review
}

Journal of Innate

Immunity
J Innate Immun 2010;2:439-445

DOI: $\underline{10.1159 / 000317194}$
Received: April 12, 2010

Accepted: April 19, 2010

Published online: June 26, 2010

\section{The Harmful Role of C5a on Innate Immunity in Sepsis}

\author{
Peter A. Ward \\ Department of Pathology, University of Michigan Medical School, Ann Arbor, Mich., USA
}

\section{Key Words}

Sepsis $\cdot \mathrm{C} 5 \mathrm{a} \cdot \mathrm{C}$ a receptors $\cdot$ Defective signaling

\begin{abstract}
There is accumulating evidence in humans and in experimental sepsis that robust activation of the complement system occurs along with development of defects in the innate immune system. In this report we review evidence that the complement activation product, $\mathrm{C} 5 \mathrm{a}$, appears in the plasma of rodents following cecal ligation and puncture (CLP). C5a interacts with its receptors $(\mathrm{C} 5 \mathrm{aR}, \mathrm{C} 5 \mathrm{~L} 2)$ on phagocytes (polymorphonuclear neutrophils, PMNs, macrophages), ultimately paralyzing the ERK $1 / 2$ pathway of the mitogen-activated protein kinase signaling pathway. $\mathrm{C} 5 \mathrm{a}$ is also interactive with its receptors on a variety of other cell types in various organs. Interaction of $\mathrm{C} 5 \mathrm{a}$ with receptors on PMNs results in compromised innate immunity, with intense suppression of phagocytosis, chemotaxis and the respiratory burst. Endothelial cells acquire a pro-inflammatory phenotype (increased ICAM-1 and tissue factor expression), while macrophages are primed and produce large amounts of cytokines/chemokines. All of these outcomes are C5a and C5a receptor dependent. CLP also unleashes activation of clotting (and fibrinolytic) factors in a C5a-dependent manner. Finally, thymocytes upregulate $\mathrm{C} 5 \mathrm{aR}$ and react with $\mathrm{C} 5 \mathrm{a}$, re-
\end{abstract}

sulting in apoptosis via the intrinsic (mitochondrial) pathway. Collectively, these findings suggest that interception of C5a in sepsis preserves innate immune functions and may be a strategy for treatment of septic humans.

Copyright $\odot 2010$ S. Karger AG, Basel

\section{Introduction}

The defensive responses in sepsis involve engagement of the innate immune system in an attempt to contain and remove offending microorganisms by locally triggering a robust acute inflammatory response at the site of infection. In sepsis, this response often becomes systemically expressed. There is strong evidence that both the Toll-like receptor and complement systems are brought into play as the body tries to contain the offending microorganisms. It is well known that these responses may result in a successful assault on the microorganisms, resulting in their containment and cessation of the inflammatory response, with return to homeostasis. Unfortunately, for $30-50 \%$ of septic patients in North America, the inflammatory response continues and becomes greatly exaggerated, resulting in septic shock and lethality [1]. In the course of progression of the septic state, there is evidence for a 'cytokine storm' which is defined by the pres-

\section{KARGER}

Fax +4161306 1234

E-Mail karger@karger.ch

www.karger.com (c) 2010 S. Karger AG, Basel

Accessible online at: www.karger.com/jin
Dr. Peter A. Ward

Department of Pathology, University of Michigan Medical School

1301 Catherine Rd. Box 5602

Ann Arbor, MI 48109-5602 (USA)

Tel. +1 734647 2921, Fax +1 734764 4308, E-Mail pward@umich.edu 
Table 1. Evidence for harmful effects of C5a in sepsis

1 Protective effects of neutralizing polyclonal antibodies to C5a
in CLP rats:
a Enhanced survival
b Reduced defects in innate immune system
c Reduced multiorgan failure
d Reduced intensity of coagulopathy

2 Protective effects of absence or blockade of C5a receptors in CLP mice:

a Requirement for blockade or absence of both C5aR and C5L2

b Improved survival

c Reduced cytokine storm

d Role of C5L2 in production of HMGB1

3 Unexpected effects of CLP in C5 $5^{-/-}$mice

ence in serum/plasma of numerous pro-inflammatory cytokines and chemokines. Precisely why this occurs and to what extent these mediators are responsible for development of multiorgan failure (involving heart, lungs, kidneys and liver) is entirely unknown. We will provide a brief review for the role of the complement system in the setting of sepsis both in humans and in animals with an emphasis on generation of $\mathrm{C} 5 \mathrm{a}$ and its engagement with $\mathrm{C} 5 \mathrm{a}$ receptors $(\mathrm{C} 5 \mathrm{aR}, \mathrm{C} 5 \mathrm{~L} 2)$, the result of which leads to a large number of life-threatening outcomes in a variety of organs.

\section{Evidence for Complement Activation in Humans with Sepsis}

It has been known for some time that in septic humans there is robust activation of the complement system, as signified by the loss of the hemolytic activity of complement (CH50) and by the appearance in plasma of complement activation products, namely, the complement anaphylatoxins, $\mathrm{C} 3 \mathrm{a}$ and $\mathrm{C} 5 \mathrm{a}$, which can be measured by ELISA technology [2, 3]. In humans, the levels of C5a can rise to levels as high as $100 \mathrm{~nm}$ [2]. Coincident with complement activation is impairment of innate immune functions of blood neutrophils (polymorphonuclear neutrophils, PMNs), involving chemotaxis, phagocytosis and the respiratory burst (associated with activation of NADPH oxidase, NOX2) [4]. Of considerable interest is the finding that the impaired chemotactic responses are globally affected, since neutrophils (PMNs) develop defective responses not only to C5a but also to the structurally unrelated and bacterially derived che- motactic molecule, $\mathrm{N}$-formyl-Met-Leu-Phe $[2,4]$. Such data suggest that signaling pathways involving $G$ protein-coupled receptors, which seem to converge downstream, have become defective, resulting in global dysfunction of innate immune responses in PMNs. It is important to emphasize that reports describing defects in innate immune responses of blood leukocytes from septic humans have often involved relatively small groups of patients and frequently have lacked sequential measurements over time in order to define the kinetics of such events. The absence of such information makes it very difficult to compare various reports and to know to what extent findings in sepsis can be put into a reliable framework of knowledge.

\section{Complement Activation and Role of C5a in Experimental Sepsis}

We will deal with evidence for the adverse roles of $\mathrm{C} 5 \mathrm{a}$ as well as $\mathrm{C} 5 \mathrm{a}$ receptors $(\mathrm{C} 5 \mathrm{aR}, \mathrm{C} 5 \mathrm{~L} 2)$ in experimental sepsis. Several decades ago, monkeys infused intravenously with live Escherichia coli showed evidence of complement activation [5]. The copresence of a rabbit polyclonal antibody to $\mathrm{C} 5 \mathrm{a}$ in this model resulted in neutralization of C5a, attenuating some of the features of sepsis such as shock, oxygen consumption and development of the acute respiratory distress syndrome [6]. There were suggestions that mortality rates in the anti-C5a-treated monkeys were reduced, but the number of monkeys was too small to obtain statistical significance that would link C5a neutralization to attenuated pathophysiological changes and improved survival.

Most of the work dealing with the role of $\mathrm{C} 5 \mathrm{a}$ and $\mathrm{C} 5 \mathrm{a}$ receptors in the setting of sepsis (cecal ligation and puncture, CLP) has been done in our own laboratories, using the rat and rodent models of CLP. Technical details of the CLP model in rodents have been recently described [7]. The data outlining evidence for the linkage between C5a and its receptors in the setting of sepsis are briefly summarized in table 1 . The first strong hint for the adverse role of C5a in CLP rats came from the finding that intravenous infusion of neutralizing polyclonal antibody to rat C5a was highly protective, caused reduced evidence of multiorgan failure and resulted in dramatically improved survival (from $0 \%$ survival in the unprotected to $50 \%$ survival in rats treated with neutralizing antibody to C5a) $[4,8]$. In successive studies, treatment of either CLP rats or mice with neutralizing antibodies (polyclonal or monoclonal antibodies, $\mathrm{mAb}$ ) to $\mathrm{C} 5 \mathrm{a}$ resulted 
in improvements in survival and was found to be related to amount of antibody infused (intravenously) at the time of CLP as well as the time of administration of the antibody [9]. Such treatment greatly reduced evidence of multiorgan dysfunction [10]. Several important observations arose from these studies. When the rabbit polyclonal IgG was employed and given intravenously at the time of CLP, the protective effects in rats (survival over a 10-day period) were directly related to the dose of antibody employed $(200,400,600 \mu \mathrm{g})$. The antibodies that were affinity purified were directed towards three different peptide regions of rat $\mathrm{C} 5 \mathrm{a}$ : the $\mathrm{N}$-terminal area (residues 1-16), the mid-region of C5a (residues 17-36) and the C-terminal region (residues 58-77). The most protective antibodies were those directed at the mid- and $\mathrm{C}$-terminal regions of $\mathrm{C} 5 \mathrm{a}$. By the use of these synthetic peptides for each of the three regions of $\mathrm{C} 5 \mathrm{a}$, it was possible to demonstrate that they could reduce chemotactic responses of rat PMNs to intact $\mathrm{C} 5 \mathrm{a}$, thereby establishing that $\mathrm{C} 5 \mathrm{a}$ binds to $\mathrm{C} 5 \mathrm{aR}$ at at least three different sites, which seems unusual for a $G$ protein-coupled receptorligand interaction. Such data infer that at least three different regions on C5a could be targeted to reduce the ability of C5a to interact with its receptor(s). The use of $600 \mu \mathrm{g}$ of antibody targeted at the mid- or C-terminal regions of $\mathrm{C} 5$ a improved survival over 10 days from $23 \%$ in rats receiving pre-immune IgG to $83-90 \%$ survival in rats given antibodies to the mid- or C-terminal or midregions of $\mathrm{C} 5 \mathrm{a}$.

Another fascinating outcome of these studies was the fact that the polyclonal antibodies to $\mathrm{C} 5 \mathrm{a}$, when added to normal rat serum, did not inhibit C5b-9-dependent lysis of sensitized rabbit red cells [11]. In other words, the antibodies behaved like $\mathrm{mAbs}$ that could recognize $\mathrm{C} 5 \mathrm{a}$ only after it had been cleaved from C5 but not when it was still present in intact C5. This implies that C5a, when released from its parent molecule, undergoes a conformational change that results in expression of a unique epitope. Such observations are important, since, if such an anti-C5a were to be used in humans, it would neutralize $\mathrm{C} 5$ a but would not cause $\mathrm{C} 5$ depletion, resulting in loss of C5b-9 generation and compromising the lytic ability of C5b-9 for Gram-negative bacteria.

Finally, these studies showed that the protective effects of anti-C5a antibodies to the mid- or C-terminal regions of rat $\mathrm{C} 5 \mathrm{a}$ were, as expected, time dependent based on induction of CLP. When given at time 0 of CLP, $90 \%$ survival was found; when delayed until $6 \mathrm{~h}$ after CLP, survival was still approximately $60 \%$; when infusion of antiC5a was delayed until $12 \mathrm{~h}$ after CLP, survival was still
$40-50 \%$. Such data infer that there is a substantial 'window' after onset of sepsis when antibody-induced neutralization of C5a is still efficacious. Similar data have been found using mouse neutralizing $\mathrm{mAbs}$ to rat $\mathrm{C} 5 \mathrm{a}$ (data not shown). In addition to being highly protective (defined as greatly improved survival), these interventions substantially reduced the intensity of multiorgan failure as defined by diminished levels of plasma lactate, transaminases, creatinine and blood urea nitrogen $[4$, 10].

The time frame for sepsis development after CLP occurs in a short period of approximately 3 days in rodents. The early phase (in the first $36 \mathrm{~h}$ ) is the 'hyperdynamic' phase featuring, among other things, fever, tachycardia, increased cardiac output and leukocytosis. The late phase (between 36 and $72 \mathrm{~h}$ ) is the 'hypodynamic' phase characterized by hypothermia, shock, bradycardia, tachypnea and falling core body temperature, among other things. In humans, the sequence of pathophysiological events in sepsis is more spread out, often occurring over 4-6 days. Based on the protective effects of delayed infusion of anti-C5a into CLP rats (described above), it is possible that such a therapeutic approach in septic humans might still be effective when patients enter the phase of septic shock.

Another strategy used in CLP mice was employment of a cyclical inhibitor of C5aR (and also C5L2), which blocks the ability of C5a to react with its receptors [12]. This compound was highly effective in enhancing survival of CLP mice [13]. The intensity of the coagulopathy of sepsis was greatly attenuated in CLP rats (for example, clotting times were minimally prolonged, thrombocytopenia was reduced and plasma levels of fibrin split products as well as thrombin-antithrombin complexes were greatly reduced) as a result of neutralization of C5a after CLP [14].

\section{Roles of C5a Receptors in Experimental Sepsis}

Based on the key role of C5a in sepsis (as described above), the crucial issue deals with the possible coordinate roles of C5aR and C5L2 in the setting of experimental sepsis. Aside from interception of C5a in sepsis (as described above), blockade of C5a receptors is an alternative approach. However, it is essential to know which receptor is dominant in sepsis or whether both participate, in order to assess a receptor blocking strategy. Figure 1 shows a scheme in which CLP-induced sepsis in rodents induces complement activation, resulting in $\mathrm{C} 5$ a produc- 
Fig 1. Roles of C5a and C5a receptors in experimental sepsis.

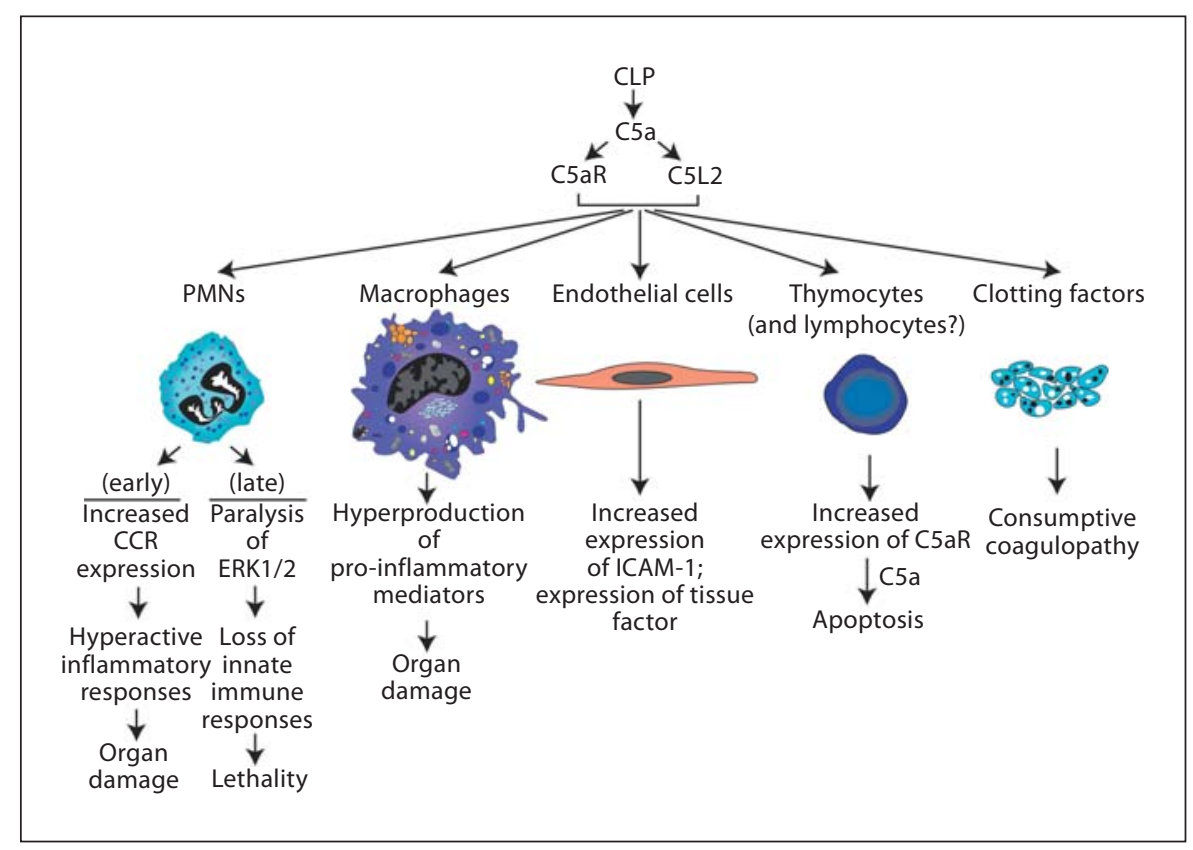

tion and engagement of both C5aR and C5L2 in a variety of cell targets that bear these receptors (PMNs, macrophages, endothelial cells, thymocytes and perhaps lymphocytes, as well as organs such as lung, liver, spleen, heart and kidneys). As indicated above, sepsis is associated with the appearance of $\mathrm{C} 5 \mathrm{a}$ (and C5a desArg) as well as C3a (and C3a desArg) in plasma. C5a and C5a desArg interact with $\mathrm{C} 5 \mathrm{aR}$ (CD88) and C5L2, each of which is a seven-membrane spanning receptor. C5L2 also appears to interact with C3a desArg [17]. Engagement of C5aR with $\mathrm{C} 5 \mathrm{a}$ causes $\mathrm{C} 5 \mathrm{aR}$ to engage with the $\mathrm{G}$ protein system, resulting in a rapid cytosolic $\mathrm{Ca}^{2+}$ transient and rapid intracellular translocation of the $\mathrm{C} 5 \mathrm{a} \cdot \mathrm{C} 5 \mathrm{aR}$ complex. Because of an amino acid substitution in the DRY region of the second intracellular loop of C5L2, engagement of this receptor with $\mathrm{C} 5$ a does not result in $\mathrm{G}$ protein-coupled activation and, thereby, no $\mathrm{Ca}^{2+}$ transient occurs [15-19]. Somewhat surprisingly, the bulk of C5L2 appears to be chiefly within intracellular granules of PMNs [20, 21]. As $\mathrm{C} 5 \mathrm{a} \cdot \mathrm{C} 5 \mathrm{aR}$ translocates into the cytoplasm, it appears to associate with $\mathrm{C} 5 \mathrm{~L} 2$, whereupon signal transduction occurs in a manner that may represent the competing influences of C5aR (positive outcomes) and C5L2 (negative outcomes). These interactions and subsequent responses of phagocytes appear to be contained by the binding of $\beta$-arrestin to the C5a receptors [20]. On balance, while activation of C5aR clearly leads to ERK1/2 activation, the extent to which C5L2 interacting with C5a affects ERK1/2 activation is a subject of considerable contention. In PMNs from C5L2 $2^{-/-}$mice, in nonmyeloid cells transfected to express C5L2 or in wild-type (Wt) PMNs in which C5L2 has been blocked with an antibody, one group argues that under such conditions engagement of C5L2 seems to attenuate ERK1/2 activation linked to $\mathrm{C} 5 \mathrm{a} \cdot \mathrm{C} 5 \mathrm{aR}$ engagement [20]. It seems clear that ERK1/2 activation (phosphorylation) is linked to C5a interacting with C5aR [22]. In contrast, another group reports that, in the absence of C5L2, reduced activation of ERK1/2 occurs [23]. It is currently not possible to reconcile these divergent views.

There is strong evidence recently obtained that both $\mathrm{C} 5 \mathrm{aR}$ and $\mathrm{C} 5 \mathrm{~L} 2$ contribute to the adverse outcomes of sepsis. As indicated above, in CLP mice treated with a synthetic, cyclic inhibitor which blocks both $\mathrm{C} 5 \mathrm{aR}$ and C5L2 [13], infusion of a competing peptide that blocks both receptors [24] or after the use of mice lacking one of the two C5a receptors and also treated with a blocking antibody to the other receptors [24], there was considerably improved survival following CLP. Our group has also described in CLP mice that antibody-induced blockade of C5L2 resulted in significantly increased (by 3 -fold) levels of IL- 6 in the plasma, suggesting that C5L2 in some manner regulates the cytokine appearance in plasma under conditions of CLP [25]. When $\mathrm{Wt}, \mathrm{C}^{2} \mathrm{aR}^{-/-}$and $\mathrm{C} 5 \mathrm{~L} 2^{-1-}$ mice (all on a C57Bl/6 background) were used in the mild and severe CLP models of sepsis [7], it was fairly 
clear that in the severe form of sepsis the absence of $\mathrm{C} 5 \mathrm{aR}$ together with antibody-induced blockade of C5L2 resulted in significantly improved survival (going from $0 \%$ survival up to $80 \%$ ) [24]. In the mild form of sepsis, absence of C5L2 as compared to Wt mice also led to improved survival (from 40 to $80 \%$ ) in C5L2 ${ }^{-/-}$mice [24]. Interestingly, in either $\mathrm{C}_{5} \mathrm{aR}^{-/-}$or $\mathrm{C} 5 \mathrm{~L}^{-/-}$mice, levels of various cytokines and chemokines in the cytokine storm were in general substantially reduced $(\geq 80 \%)$ after CLP. This pattern suggests that the sepsis-induced cytokine storm may occur in a sequential fashion and in a manner that requires $\mathrm{C} 5 \mathrm{a}$ engagement of both $\mathrm{C} 5 \mathrm{aR}$ and $\mathrm{C} 5 \mathrm{~L} 2$. Another important observation obtained from these studies was that C5L $2^{-1-}$ mice after CLP had greatly reduced levels of HMGB1, which is a well-known transcription factor that appears in plasma after CLP or endotoxemia and whose blockade in these models of sepsis is protective [26]. Interestingly, in $\mathrm{C}^{2} \mathrm{aR}^{-/-}$mice after CLP, there was no reduction in plasma levels of HMGB1 [24]. Furthermore, peritoneal exudate macrophages from $\mathrm{Wt}$ or $\mathrm{C} \mathrm{aR}^{-/-}$mice produced HMGB1 when stimulated with LPS, whereas macrophages from $\mathrm{C} 5 \mathrm{~L} 2^{-/-}$mice showed no HMGB1 production. Accordingly, HMGB1 expression from LPS-stimulated peritoneal macrophages is a function of C5L2 but not C5aR. However, as described above, the bulk of cytokines and chemokines expressed in plasma after CLP requires participation of both C5aR and C5L2.

Early after CLP, PMNs show a gain of function by expressing CCL1, CCL2 and CCL5 [27], which would be expected to lead to pro-inflammatory outcomes. Ordinarily, these receptors are expressed in small amounts, if at all, on PMNs and these cells respond very poorly to ligands for these receptors, based on chemotaxis as the functional endpoint. Blood PMNs after CLP show increased binding of MCP-1 and MIP- $1 \alpha$ and acquire the ability to respond chemotactically in vitro to these chemokines [27]. Non-CLP PMNs are ordinarily nonresponsive to these chemokines. In addition, CLP causes blood PMNs to show increased expression of $\beta_{1}$ integrins (CD29) and $\beta_{2}$ integrins (CD18), indicating a hyperresponsiveness to the 'counter receptors' for these integrins [28]. Collectively, these data demonstrate that, in the early stages after CLP, blood PMNs develop an exaggerated ability to respond to a variety of inflammatory mediators. As indicated above, as time progresses after CLP, the MAPK (ERK1/2) pathways in PMNs become paralyzed in a C5a-dependent manner [4] and lose innate immune functions (phagocytosis, chemotaxis, respiratory burst), causing an inability to clear gut-derived bacteria from blood and from the peritoneal cavity. In rodents with CLP, these bacteria are both Gram-positive and -negative). Under these conditions, the respiratory burst in blood PMNs becomes defective and assembly of NADPH oxidase (NOX2) is greatly impaired due to an inability to translocate from the cytosol critical subunits (such as $\mathrm{p} 47^{\mathrm{phox}}$ ) of the oxidase to the cell membrane, indicating that the ability to generate $\mathrm{H}_{2} \mathrm{O}_{2}$ for MPO-dependent killing of ingested bacteria is greatly reduced (fig. 1) [4]. It is clear that such defects are C5a dependent and can be largely averted after CLP by in vivo neutralization of C5a [4]. Macrophage interaction with $\mathrm{C} 5$ a does not result in impairment of signaling pathways for reasons that are not understood. This may be due to the fact that binding sites for $\mathrm{C} 5 \mathrm{a}$ on macrophages are far fewer when compared to the number of sites on PMNs. The chief effect of C5a on macrophages is their 'priming' and greatly enhanced production of pro-inflammatory mediators, likely related to the cytokine storm in sepsis which is followed by multiorgan failure. Endothelial cells during sepsis have increased expression of ICAM-1 as well as tissue factor, both being linked to interaction of these cells with C5a [29]. In this manner, endothelial cells bind many more $\mathrm{PMNs}$ resulting in increased translocation of PMNs into organs. As well, endothelial cells with their increased surface content of tissue factors now enhance the likelihood of intravascular clots. Thymocytes as early as $3 \mathrm{~h}$ after sepsis have increased expression of $\mathrm{C} 5 \mathrm{aR}$ and then undergo apoptosis via the internal (mitochondrial) pathway of apoptosis [30]. Whether this also occurs in T and $\mathrm{B}$ cells which become apoptotic very early in the setting of sepsis [31] is unclear. Finally, sepsis induces the wellknown phenomenon of consumptive coagulopathy. This is characterized by platelet activation together with activation and consumption depletion of clotting factors, as the clotting cascade is activated following the conversion of prothrombin to thrombin. These events lead to reduction of clotting factors in blood, platelet depletion and presence of thrombin-antithrombin complexes and fibrin split products, among others. Concurrent with activation and depletion of clotting factors during sepsis is activation of the fibrinolytic system, whose function is to bring about conversion of plasminogen to plasmin, which is the major serine protease that degrades fibrin into fibrin split products. Removal of fibrin from the luminal surfaces of vessels or from extravascular locales is critical, inefficient removal of fibrin deposits can lead to more and more fibrin deposition, resulting in vascular occlusion and thrombus formation as well as fibrosis in areas of peripheral lung if fibrin breakdown is insufficient. In 
vivo blockade of C5a in CLP rats reverses most of the features of coagulopathy [loss of clotting factors, thrombocytopenia, prolonged clotting times, continued presence of products of clotting (such as thrombin-antithrombin complexes) and fibrin split products, among others] [14]. How and why C5a interception after CLP curtails the consumptive coagulopathy of sepsis is not at all understood. Such outcomes might be linked to the well-known interconnections between the complement and the clotting cascades [32]. In general, the ability of C5a neutralization to greatly reduce the complications of experimental sepsis has great appeal, since the only FDA-approved drug for human sepsis is recombinant activated protein $\mathrm{C}$, which is intrinsically an anticoagulant. Using an anticoagulant in a condition (sepsis) in which consumptive coagulation is occurring means that strict limitations in its use are mandatory.

\section{Unexpected Effects of CLP in $\mathrm{C5}^{-/-}$Mice}

There have been several lessons learned about molecular events occurring in sepsis vis-à-vis the role of C5, C5 activation products (C5a, C5b-9) and $\mathrm{C} 5 \mathrm{a}$ receptors. Based on all of the evidence presented above, the predictions to be drawn from the use of $\mathrm{C}^{-/-}$mice would be that, since no C5a can be generated, these mice should be well protected from the adverse events of sepsis, assuming that $\mathrm{C} 5 \mathrm{a}$ and its receptors are 'major players' in the harmful outcomes of experimental sepsis. The surprise which we recently uncovered was that $\mathrm{C}^{-/-}$mice had no survival advantage compared to Wt CLP mice [33]. Using the high-grade intensity of CLP [7], by day 5 all mice in both groups (Wt, $\mathrm{C5}^{-/-}$) were dead. Clearly, absence of C5 conferred no survival advantage. When plasma samples were examined for mediator content, in $\mathrm{C}^{-/-} \mathrm{CLP}$ mice
TNF- $\alpha$ levels were elevated by $64 \%$ compared to Wt mice, while other mediators (IL-1 $\beta$, IL-6, MCP-1 and MIP-2) were reduced by $36-89 \%$. Clearly, the absence of C5 in some manner caused downward deflection in the cytokine storm. One of the most interesting differences between the Wt and $\mathrm{C}_{\mathrm{aR}} \mathrm{R}^{-/-}$CLP mice was that blood colony-forming units (CFUs) in Wt mice were around $2 \times$ $10^{5} \mathrm{CFUs} / \mathrm{ml}$ blood, while the CFUs in blood from $\mathrm{C}^{-/-}$ mice were $\geq 900 \times 10^{5} \mathrm{CFUs} / \mathrm{ml}$ blood. In the absence of C5, no C5b-9 which can be formed, loss of which seems to be associated with a serious derangement in bacterial clearance. Therefore, the protective effects of C5b-9 have been lost in the absence of $\mathrm{C} 5$, suggesting that in experimental sepsis, C5a, which is robustly produced in CLP, has widespread harmful effects (as emphasized in fig. 1), while C5b-9 has protective effects by reducing CFU content in blood. As a result, the absence of $\mathrm{C} 5$ prevents the harmful effects of C5a, but the protective effects of C5b-9 are nullified in $\mathrm{C}^{-/-}$mice after CLP. Such observations imply that great caution is often needed in interpreting data from knockout mice. Another example of problems interpreting data from knockout mice was our observation that $\mathrm{C}^{-/-}$mice developed full-fledged lung injury after intrapulmonary deposition of IgG immune complexes [32]. The surprising finding was the presence of $\mathrm{C} 5 \mathrm{a}$ in their lungs. It was ultimately shown that C5a was generated by the interaction of thrombin with $\mathrm{C} 5$, also underscoring the linkages between the complement and clotting systems. The data described above suggest that it may be inadvisable to use C5-depleting antibodies in the setting of sepsis in humans.

\section{Acknowledgement}

This research was supported in part by NIH grant GM-61656.

\section{References}

1 Dellinger RP, Levy MM, Carlet JM, Bion J, Parker MM, Jaeschke R, Reinhart K, Angus DC, Brun-Buisson C, Beale R, Calandra T, Dhainaut JF, Gerlach H, Harvey M, Marini JJ, Marshall J, Ranieri M, Ramsay G, Sevransky J, Thompson BT, Townsend S, Vender JS, Zimmerman JL, Vincent JL: Surviving Sepsis Campaign: international guidelines for management of severe sepsis and septic shock. Intensive Care Med 2008;34:17-60.
2 Solomkin JS, Jenkins MK, Nelson RD, Chenoweth D, Simmons RL: Neutrophil dysfunction in sepsis. II. Evidence for the role of complement activation products in cellular deactivation. Surgery 1981;90:319-327.

- 3 Goya T, Morisaki T, Torisu M: Immunologic assessment of host defense impairment in patients with septic multiple organ failure: relationship between complement activation and changes in neutrophil function. Surgery 1994;115:145-155.
4 Huber-Lang MS, Younkin EM, Sarma JV, McGuire SR, Lu KT, Guo RF, Padgaonkar VA, Curnutte JT, Erickson R, Ward PA: Complement-induced impairment of innate immunity during sepsis. J Immunol 2002; 169:3223-3231.

5 Hangen DH, Stevens JH, Satoh PS, Hall EW, O'Hanley PT, Raffin TA: Complement levels in septic primates treated with anti-C5a antibodies. J Surg Res 1989;46:195-199. 
6 Stevens JH, O’Hanley P, Shapiro JM, Mihm FG, Satoh PS, Collins JA, Raffin TA: Effects of anti-C5a antibodies on the adult respiratory distress syndrome in septic primates. J Clin Invest 1986;77:1812-1816.

-7 Rittirsch D, Huber-Lang M, Flierl M, Ward PA: Immunodesign of experimental sepsis by cecal ligation and puncture. Nat Protoc 2009;4:31-36.

8 Czermak BJ, Sarma V, Pierson CL, Warner RL, Huber-Lang M, Bless NM, Schmal H, Friedl HP, Ward PA: Protective effects of C5a blockade in sepsis. Nat Med 1999;5:788-792.

9 Huber-Lang MS, Sarma JV, McGuire SR, Lu KT, Guo RF, Padgaonkar VA, Younkin EM, Laudes IJ, Riedemann NC, Younger JG, Ward PA: Protective effects of anti-C5a peptide antibodies in experimental sepsis. FASEB J 2001;15:568-570.

$>10$ Huber-Lang M, Sarma VJ, Lu KT, McGuire SR, Padgaonkar VA, Guo RF, Younkin EM, Kunkel RG, Ding J, Erickson R, Curnutte JT, Ward PA: Role of C5a in multiorgan failure during sepsis. J Immunol 2001;166:11931199.

-11 Huber-Lang MS, Sarma JV, McGuire SR, Lu KT, Padgaonkar VA, Younkin EM, Guo RF, Weber $\mathrm{CH}$, Zuiderweg RR, Zetoune FS, Ward PA: Structure-function relationships of human C5a and C5aR. J Immunol 2003; 170:6115-6124.

12 Finch AM, Wong AK, Paczkowski NJ, Wadi SK, Craik DJ, Fairlie DP, Taylor SM: Lowmolecular-weight peptidic and cyclic antagonists of the receptor for the complement factor C5a. J Med Chem 1999;42:1965-1974.

-13 Huber-Lang MS, Riedeman NC, Sarma JV, Younkin EM, McGuire SR, Laudes IJ, Lu KT, Guo RF, Neff TA, Padgaonkar VA, Lambris JD, Spruce L, Mastellos D, Zetoune FS, Ward PA: Protection of innate immunity by $\mathrm{C} 5 \mathrm{aR}$ antagonist in septic mice. FASEB J 2002;16: 1567-1574.

14 Laudes IJ, Chu JC, Sikranth S, Huber-Lang M, Guo RF, Riedemann N, Sarma JV, Schmaier AH, Ward PA: Anti-c5a ameliorates coagulation/fibrinolytic protein changes in a rat model of sepsis. Am J Pathol 2002;160:1867-1875.
15 Lee H, Whitfeld PL, Mackay CR: Receptors for complement $\mathrm{C} 5 \mathrm{a}$. The importance of $\mathrm{C} 5 \mathrm{aR}$ and the enigmatic role of C5L2. Immunol Cell Biol 2008;86:153-160.

$\checkmark 16$ Okinaga S, Slattery D, Humbles A, Zsengeller Z, Morteau O, Kinrade MB, Brodbeck RM, Krause JE, Choe HR, Gerard NP, Gerard C: C5L2, a nonsignaling C5a binding protein. Biochemistry 2003;42:9406-9415.

17 Kalant D, Cain SA, Maslowska M, Sniderman AD, Cianflone K, Monk PN: The chemoattractant receptor-like protein $\mathrm{C} 5 \mathrm{~L} 2$ binds the C3a des-Arg77/acylation-stimulating protein. J Biol Chem 2003;278:1112311129.

18 Kalant D, MacLaren R, Cui W, Samanta R, Monk PN, Laporte SA, Cianflone K: C5L2 is a functional receptor for acylation-stimulating protein. J Biol Chem 2005;280:2393623944.

19 Cain SA, Monk PN: The orphan receptor C5L2 has high affinity binding sites for complement fragments C5a and C5a des-Arg(74). J Biol Chem 2002;277:7165-7169.

20 Bamberg CE, Mackay CR, Lee H, Zahra D, Jackson J, Lim YS, Whitfeld PL, Craig S, Corsini E, Lu B, Gerard C, Gerard NP: The C5a receptor $(\mathrm{C} 5 \mathrm{aR}) \mathrm{C} 5 \mathrm{~L} 2$ is a modulator of C5aR-mediated signal transduction. J Biol Chem 2010;285:7633-7644

-21 Scola AM, Johswich KO, Morgan BP, Klos A, Monk PN: The human complement fragment receptor, $\mathrm{C} 5 \mathrm{~L} 2$, is a recycling decoy receptor. Mol Immunol 2009;46:1149-1162.

22 Riedemann NC, Guo RF, Hollmann TJ, Gao H, Neff TA, Reuben JS, Speyer CL, Sarma JV, Wetsel RA, Zetoune FS, Ward PA: Regulatory role of C5a in LPS-induced IL- 6 production by neutrophils during sepsis. FASEB J 2004; 18:370-372.

23 Chen NJ, Mirtsos C, Suh D, Lu YC, Lin WJ, McKerlie C, Lee T, Baribault H, Tian H, Yeh WC: C5L2 is critical for the biological activities of the anaphylatoxins C5a and C3a. Nature 2007;446:203-207.

24 Rittirsch D, Flierl MA, Nadeau BA, Day DE, Hoesel LM, Zetoune FS, MacKay CR, Cianflone K, Gerard NP, Huber-Lang MS, Köhl J, Gerard C, Sarma JV, Ward PA: Functional roles for C5a receptors in sepsis. Nat Med 2008;14:551-557.
25 Gao H, Neff TA, Guo RF, Speyer CL, Sarma JV, Tomlins S, Man Y, Riedemann NC, Hoesel LM, Younkin EM, Zetoune FS, Ward PA: Evidence for a functional role of the second C5a receptor, C5L2. FASEB J 2005; 19: 1003-1005.

26 Wang H, Bloom O, Zhang M, Vishnubhakat JM, Ombrellino M, Che J, Frazier A, Yang H, Ivanova S, Borovikova L, Manogue KR, Faist E, Abraham E, Andersson J, Andersson U, Molina PE, Abumrad NN, Sama A, Tracey KJ: HMG-1 as a late mediator of endotoxin lethality in mice. Science 1999;285:248-251.

-27 Speyer CL, Gao H, Rancilio NJ, Neff TA Huffnagle GB, Sarma JV, Ward PA: Novel chemokine responsiveness and mobilization of neutrophils during sepsis. Am J Pathol 2004;165:2187-2196.

28 Guo RF, Riedemann NC, Laudes IJ, Sarma VJ, Kunkel RG, Dilley KA, Paulauskis JD, Ward PA: Altered neutrophil trafficking during sepsis. J Immunol 2002;169:307-314.

-29 Laudes IJ, Guo RF, Riedemann NC, Speyer C, Craig R, Sarma JV, Ward PA: Disturbed homeostasis of lung intercellular adhesion molecule-1 and vascular cell adhesion molecule-1 during sepsis. Am J Pathol 2004;164: 1435-1445.

30 Riedemann NC, Guo RF, Laudes IJ, Keller K, Sarma VJ, Padgaonkar V, Zetoune FS, Ward PA: C5a receptor and thymocyte apoptosis in sepsis. FASEB J 2002;16:887-888.

- 31 Hotchkiss RS, Tinsley KW, Swanson PE, Schmieg RE Jr, Hui JJ, Chang KC, Osborne DF, Freeman BD, Cobb JP, Buchman TG, Karl IE: Sepsis-induced apoptosis causes progressive profound depletion of $\mathrm{B}$ and CD4+ T lymphocytes in humans. J Immunol 2001;166:6952-6963.

-32 Huber-Lang M, Sarma JV, Zetoune FS, Rittirsch D, Neff TA, McGuire SR, Lambris JD, Warner RL, Flierl MA, Hoesel LM, Gebhard F, Younger JG, Drouin SM, Wetsel RA, Ward PA: Generation of C5a in the absence of C3: a new complement activation pathway. Nat Med 2006;12:682-687.

33 Flierl MA, Rittirsch D, Nadeau BA, Day DE, Zetoune FS, Sarma JV, Huber-Lang MS, Ward PA: Functions of the complement components $\mathrm{C} 3$ and $\mathrm{C} 5$ during sepsis. FASEB J 2008;22:3483-3490. 